\title{
West and East in Ashkenaz in the Time of Judah he-Hasid
}

\author{
RAINER JOSEF BARZEN \\ University of Münster, Münster, Germany \\ E-mail: barzen@uni-muenster.de
}

Accepted: 4 October 2019 / Published online: 20 April 2021

\begin{abstract}
The present study interprets and frames a long-standing question concerning Judah he-Hasid's motivations in migrating to Regensburg against the social and geographical contexts of the Jews of Ashkenaz. By examining the use of Hebrew geographic terminology during the High Middle Ages (Loter, Ashkenaz, Ashkelonia), the article demonstrates that twelfth-century Jews perceived and were engaged in contemporary political and territorial processes of the surrounding kingdom. The Hebrew terms describe the cultural tripartite division of the German kingdom (Regnum Teutonicum) in Lotharingia, the five duchies of the earlier tribes (Saxony, Franconia, Thuringia, Swabia, and Bavaria), and the still Slavic territories of the East. These imperial territories were settled and Christianized by mostly German migrants from the west of the kingdom from the eleventh century onwards. Comparable developments are evident in the movement and expansion of Jewish settlement in the German Kingdom. After many Jewish communities were founded in the Ashkenazic heartlands, beginning in cities on the Rhine, Main, and the Danube, i.e., in the territories of the five duchies (Ashkenaz), Jewish settlers founded new communities and settlements in the still Slavic areas (Ashkelonia), beyond the Elbe and Saale rivers, as part of the German settlement movement. Judah he-Hasid's family's migration is part of this development. With his relocation to Regensburg, he lived on the border of the Ashkenazic heartland (Old/West Ashkenaz) and the new Ashkenazic settlement areas in Ashkelonia (New/Eastern Ashkenaz). In Regensburg he became one of the central spiritual and halakhic authorities for the communities of the eastern neighboring territories. Through his work Judah he-Hasid opened the way to an "Ashkenazation" of the Jewish communities in eastern Central Europe and Eastern Europe.
\end{abstract}

Keywords Medieval Ashkenaz · Jews in Slavic lands · German Eastern expansion · Ashkenazic migration · Judah he-Hasid

The emigration of the Kalonymous family from Speyer to Regensburg at the end of the twelfth century remains shrouded in mystery. Apart from pietistic motivations, why did Samuel, Abraham, and Judah he-Hasid leave the Rhineland? Why did they choose Regensburg as their destination? What opportunity or motivation may have played a role in the Kalonymous family moving its place of residence from the center of the German kingdom at the time (the Middle Rhine region) to its periphery (the eastern edge of the kingdom)?

I propose to answer this frequently discussed issue by framing it within the context of the settlement of Jews in Ashkenaz and the expansion of the 
Jewish settlement area to Central and Eastern Europe. Starting with the term "Ashkenaz" as the Hebrew term for the "German lands" beginning in the twelfth century, I show how Hebrew geographic terminologies of the High Middle Ages can be utilized as a reflection of general political territorial developments. I demonstrate that the Kalonymous's move to Regensburg should be understood as part of a new movement that would bring about further Jewish communal settlements in the eastern territories of the German kingdom in subsequent generations. This Jewish settlement movement can also be viewed as part of a wider pattern of settlement movement that affected the non-Jewish population of the German kingdom, which began with the domestic colonization of the western territories and between the eleventh and fourteenth centuries led to the settlement, conquest, and ethnic and economic transformation of new regions.

The Jewish side of this movement, which can be reconstructed from settlement documentation, ${ }^{1}$ is illustrated in the Hebrew terminology for geopolitical entities in high medieval Hebrew literature. A comparison of Hebrew geographical terms with contemporaneous Latin and vernacular variants and their geographical meanings helps clarify the extent to which Hebrew terms either reflected a "Jewish" perception of space or, conversely, served "only" as separate terminologies for a perception of the geopolitical world common to both Jews and Christians.

\section{The Term "Ashkenaz"}

An examination of the political and geographical usage of the word "Ashkenaz," particularly in the twelfth and thirteenth centuries, serves as a fruitful starting point for our inquiry. In the language of modern academic research, "Ashkenaz" is a constructed term first used to vaguely describe the Jews of western Europe (northern France and Germany). Later, with the growing scholarly awareness of the complexities of European medieval Jewish life, it came to signify the Jews of the German linguistic and cultural region during the High Middle Ages. In the study of the early modern period, there is

\footnotetext{
${ }^{1}$ On documentation of medieval Jewish settlements in the German lands see vols. 1-3 of Germania Judaica: vol. 1, Ismar Elbogen, Aron Freimann, Haim Tykocinski, eds., Von den ältesten Zeiten bis 1238 (Breslau, 1934); vol. 2, Zvi Avneri, ed., Von 1238 bis zur Mitte des 14. Jahrhunderts, pt. 1, Aachen-Luzern, pt. 2, Maastricht - Zwolle (Tübingen, 1968); vol. 3, 1350-1519, pt. 1, Arye Maimon, ed., Ortschaftsartikel Aach - Lychen (Tübingen, 1987); pt. 2, Arye Maimon, Mordechai Breuer, and Yacov Guggenheim, eds., Ortschaftsartikel MährischBudwitz - Zwolle (Tübingen, 1995); pt. 3, Arye Maimon, Mordechai Breuer, and Yacov Guggenheim, eds., Gebietsartikel, Einleitungsartikel und Indices (Tübingen, 2003); Alfred Haverkamp, ed., Geschichte der Juden im Mittelalter von der Nordsee bis zu den Südalpen, 3 vols., Forschungen zur Geschichte der Juden A.14/1-3 (Hannover, 2002).
} 
a tendency to use the term "Ashkenaz" for the entire settlement area of the Jews that were thereafter called "Ashkenazim," including Poland, Italy, and the Holy Roman Empire. ${ }^{2}$ This, in turn, is a scientific construct that does not necessarily conform clearly to the findings in early modern sources. ${ }^{3}$

In medieval times, the term "Ashkenaz" developed along the exact opposite trajectory. ${ }^{4}$ It was a geopolitical expression that changed and became concrete, as did the term "German lands." Originating from the biblical table of nations, ${ }^{5}$ "Ashkenaz" is first identified as a land located far north of the Land of Israel. ${ }^{6}$ This idea of a country called "Ashkenaz" far to the north seems to prevail in Hebrew literature among the Jewish sages of the Islamic world during the tenth century. ${ }^{7}$ For them, "Ashkenaz" refers to this remote country north of the Alps, at first not exclusively designated as the "Ger-

\footnotetext{
${ }^{2}$ Max Weinreich wanted to distinguish between "Ashkenaz I," the Jews of the medieval German-speaking lands, and "Ashkenaz II," the Jews of the later centers in Eastern Europe, mostly early modern Poland. According to this terminology Erika Timm speaks of "Ashkenaz III" to describe the cultural Jewish heritage in Italy of Ashkenazi origin. Max Weinreich, History of the Yiddish Language, ed. Paul Glasser, trans. Shlomo Noble (New Haven, 2008), 3-4; Erika Timm, "Das jiddischsprachige literarische Erbe der Italo-Ashkenazen," in Schöpferische Momente des europäischen Judentums in der frühen Neuzeit, ed. Michael Graetz (Heidelberg, 2000), 161. See Lucia Raspe, "The Migration of German Jews into Italy and the Emergence of Local Rites and Selihot Recitation," in The Jews of Europe around 1400: Disruption, Crisis, and Resilience, ed. Lukas Clemens and Christoph Cluse, Forschungen zur Geschichte der Juden A.27 (Wiesbaden, 2018), 174.

${ }^{3}$ On the concept of "Ashkenaz" in the early modern period see Joseph Davis, "The Reception of the 'Shulhan 'Arukh' and the Formation of Ashkenazic Jewish Identity," AJS Review 26, no. 2 (2002): 266 n. 63, with references to Max Weinreich and his research.

${ }^{4}$ Leopold Zunz, Die Ritus des synagogalen Gottesdienstes, geschichtlich entwickelt, 2nd ed. (Berlin, 1919), 66-67, n. h; Samuel Kraus, "The Names Ashkenaz and Sepharad" [in Hebrew], Tarbiz 3 (1932): 423-30; Ismar Elbogen, "Deutschland," Germania Judaica, 1:17 (on "Ashkenaz"); Samuel Kraus, "Die hebräischen Benennungen der modernen Völker," in Jewish Studies in Memory of George A. Kohout 1874-1933, ed. Salo W. Baron and Alexander Marx (New York, 1935), 387-89; Paul Rieger, "אשכנז- Deutschland," Monatsschrift für die Wissenschaft des Judentums 80/44, no. 6 (1936): 455-59; idem, "לשון כנען = die Sprachen Deutschlands," Monatsschrift für die Wissenschaft des Judentums 81/45, no. 3 (1937): 299-301; Luitpold Israel Wallach, "Zur Etymologie אשכנז-Deutschland," Monatsschrift für die Wissenschaft des Judentums 83/47 (1939): 302-4; idem, "Ashkenaz-Germany," Historia Judaica 3 (1941): 102-6; Jehuda Rosenthal, "Ashkenaz, Sepharad and Zarefat," Historia Judaica 5 (1943): 58-62; “Ashkenaz," Encyclopedia Judaica, ed. Michael Berenbaum and Fred Skolnik (Detroit, 2007), 2:569-71 (hereafter EJ).

${ }^{5}$ Gen $10: 3$.

${ }^{6}$ Jer 51:27; 1 Chr 1:6. See also Rieger, "Deutschland," 455.

${ }^{7}$ Saadya b. Joseph, Egypt (882-942); Hasdai ibn Shaprut, Cordova (tenth century); David ben Abraham al-Fasi, a Karaite lexicographer (tenth century). Wallach, "Zur Etymologie," 302-3; Wallach, "Ashkenaz = Germany," 103; Rosenthal, "Ashkenaz," 61.
} 
man lands," "Alemania." During the eleventh and twelfth centuries these two terms were linked with each other and were used interchangeably, in the same texts, to designate the "German lands." 10

Thus, after the twelfth century the country situated between the Rhine and the Elbe has at least two names in Hebrew writings. It is called Ashkenaz, a designation that I believe reflects a more internal Ashkenazic perception, ${ }^{11}$ and Alemania, which reflects more of an external, ${ }^{12}$ Romance/French

\footnotetext{
${ }^{8}$ Interpretations by different scholars of this term varied from the Land of the Khazars to different Slavic countries. See Kraus, "Die hebräischen Benennungen," 387-89; Rieger, "Deutschland," 456; Rosenthal, "Ashkenaz," 60 n. 11.

${ }^{9}$ Rosenthal, "Ashkenaz," 61.

${ }^{10}$ As an early example for the usage of "Alemania" and "Ashkenaz" for the "German lands" in the same text see Marcus Nathan Adler, ed., The Itinerary of Benjamin of Tudela: Critical Text, Translation and Commentary (London, 1907), 71, 79. See also note 48 below. It seems that a Hebrew term for the "German lands" was needed when the "Regnum Teutonicum" came into existence. See Rieger, "Deutschland," 458-59.

${ }^{11}$ Rashi: "leshon Ashkenaz," BT Sukkah 17a; BT Gittin 55b; BT Bava Metzia 73b. "Ashkenaz," BT Ketubbot 77b; BT Ḥullin 93a. See "Ashkenaz," EJ, 2:570; "Benei Galut Ashkenaz," in Joel Müller, ed., Responsa of the Sages of Zarfat and Loter [in Hebrew] (Vienna, 1881), 11, $\S 21$; Rosenthal, "Ashkenaz," 61. Eliezer b. Nathan: "Zarfatim v-Ashkenazim" to differentiate between "French" and "Germans"; see Eva Haverkamp, Hebräische Berichte über die Judenverfolgungen während des Ersten Kreuzzuges, Monumenta Germaniae Historica: Hebräische Texte aus dem mittelalterlichen Deutschland 1 (Hannover, 2005), 249; "Eres Ashkenaz," in Simon Hurwitz, ed., Mahzor Vitry, 2 vols. (Berlin, 1893), 1:345 (§ 312), 1:392, § 353; Aryeh Goldschmidt, ed., Mahzor Vitry, 3 vols. (Jerusalem, 2003-2009), 3:784-85, § 8 and 793, § 12; Rosenthal, "Ashkenaz,” 61 n. 21. Eliezer b. Yoel ha-Levi: "Erez Ashkenaz"; see David Devlytzki, ed., Sefer Ravya, 4 vols. (Bnei Brak, 2005), 2:95, § 514; Rosenthal, "Ashkenaz," 61 n. 22. Ephraim of Bonn, Sefer Zekhirah: "Eres Ashkenaz"; see Adolf Neubauer and Moritz Stern, Hebräische Berichte über die Judenverfolgungen während der Kreuzzüge, Quellen zur Geschichte der Juden in Deutschland (Berlin, 1892), 58. "Ereș Ashkenaz," Tosafot, BT Bava Batra 74a.

${ }^{12}$ This external perspective was also explained and understood by Otto of Freising (ca. 1112-1158) in the following words: A predicto etiam Lemanno fluvio ... tota illa provincia Alemannia vocatur. Quare quidam totam Teutonicam terram Alemanniam dictam putant omnesque Teutonicos Alemannos vocare solent, cum illa tantum provincia, id est Suevia, a Lemanno fluvio vocetur Alemannia, populique eam inhabitantes solummodo iure vocentur Alemanni / "Behind the Leman River [Lake Geneva] ... the name of the whole province is called Alemannia. Therefore, some believe that according to that, all Germany (teutonicam terram) is named Alemannia and all Germans are called Alemanni, while only that province, which is Swabia (suevia) beyond the Leman River is called Alemannia and all its inhabitants are called Alemani," in Ottonis et Rahewini Gesta Friderici I. imperatoris, ed. Georg Waitz and Bernhard von Simson, Monumenta Germaniae Historica, Scriptores rerum Germanicarum in usum scholarum separatim editi 46 (Hannover, 1912), 25, quoted after Verena Türck, "Regionen in der Wahrnehmung der Zeitgenossen. Rhein-Main-Neckar-Raum, Oberitalien und Sizilien in schriftlichen und kartographischen Quellen der Stauferzeit," in Die Staufer und Italien 1:
} 
perspective. ${ }^{13}$ Thus, for the twelfth-century author of the Sefer Zekhirah, Ephraim of Bonn, "Ashkenaz" is the country in which he lives and to which he and the other Jews of the land have an emotional attachment. Coming from the land of Zarfat, he travelled through the whole land of Ashkenaz-"God may protect it. Amen." ${ }^{\prime 4}$ Is it not logical, therefore, to search for an existing, political entity behind the name "Ashkenaz" in the twelfth century?

\section{Ashkenaz and its Borders from a Western Perspective}

Is it possible to delineate the borders of this Ashkenaz and understand something about a "Jewish perception" of its inner political structure? We know that twelfth-century scholars were familiar with the internal political structures of their countries of residence. Most of the explicit references to boundaries and geopolitical entities presented here were written by Jewish scholars from Western Ashkenaz and France, who were aware of and addressed the geopolitical conditions of their time. As we will see, they know enough about Christian settlement history and geopolitical constructs to adapt their division of Jewish space to its Christian parallels. The geographical description of the effective range of the takkanot (communal ordinances) implemented by Rabbi Jacob b. Meir, known as Rabbenu Tam (d. 1171), serves as a fine example: ${ }^{15}$

Drei Innovationsregionen im mittelalterlichen Europa; Essays, ed. Alfred Wieczorek, Bernd Schneidmüller, and Stefan Weinfurter (Darmstadt, 2010), 179-181; Heinrich Pertz, ed., Annales aevi Suevici, Monumenta Germaniae Historica, Scriptores 17 (Hannover, 1861), 238; Margret Lugge, "Gallia" und "Francia" in Mittelalter: Untersuchungen über den Zusammenhang zwischen geographisch-historischer Terminologie und politischem Denken vom 6.-15. Jahrhundert, Bonner historische Forschungen 15 (Bonn, 1960), 144 n. 322; Carlrichard Brühl, Die Geburt zweier Völker: Deutsche und Franzosen (9.-11. Jahrhundert) (Cologne, 2001), 76-77.

${ }^{13}$ David Flusser, Sefer Josippon: With an Introduction Commentary and Notes [in Hebrew], 2 vols. (Jerusalem 1981), 1:6; Leopold Zunz, Literaturgeschichte der synagogalen Poesie (Berlin, 1865), 115; Ibn Ezra's and David Kimhi's commentary on Obad 1:20 (Menachem Cohen, ed., The Twelve Minor Prophets, vol. 14 of Mikra'ot Gedolot 'Haketer' [RamatGan, 2012]); Adolf Neubauer, "R. Abraham Ben David's Chronicle/Additions (Sefer haQabbalah)," in Medieval Jewish Chronicles and Chronological Notes, ed. Adolf Neubauer, Anecdota Oxoniensia: Texts Documents and Abstracts, Semitic Series, vol. 1, pt. 4 (Oxford, 1887), 84; Adler, Benjamin of Tudela, 72; Chaim Yehuda Ehrenreich, ed., Sefer haPardes: A Liturgical and Ritual Work Attributed to Rashi [in Hebrew] (Budapest, 1924; Bnei Brak, 1999), 229; Israel M. Ta-Shma, Early Franco-German Ritual and Custom [in Hebrew] (Jerusalem, 1994), 90; Yitzhak Raphael, ed., Sefer ha-Manhig of R. Abraham b. Nathan of Lunel: Rulings and Customs [in Hebrew], 2 vols. (Jerusalem, 1978), 2:602, § 156 and 627; Kraus, "Names," 432; Germania Judaica, 1:xvii-xviii, nn. 9-10 (on "Alemania").

${ }^{14}$ Neubauer and Stern, Hebräische Berichte, 58.

${ }^{15}$ Louis Finkelstein, Jewish Self-Government in the Middle Ages (New York, 1924), 155. 
Therefore have we taken counsel together, the elders of Troyes and her Sages, and those of her vicinity, the Sages of Dijon and its vicinity, the leaders of Auxere and of Sens and its suburbs, the elders of Orleans, and the vicinity, our brothers, the inhabitants of Chalons, the Sages of Reims and its county, and our masters of Paris, and their neighbors, the scholars of Melun and Etampes, and the inhabitants of Normandy, and the land of the sea [Bretagne?] ${ }^{16}$, and Anjou and Poitiers, the greatest of our generation, the inhabitants of the land of Loter [Lorraine].

This quote exhibits the author's intimate familiarity with prevailing geopolitical conditions in the kingdom of France. Moreover, the list mentions the political entity of "Lorraine/Lotharingia," 17 known in Hebrew as "Loter,"18 beyond the eastern borders of the kingdom of France.

Another, probably later transmission of the same takkanot of Rabbenu Tam emphasizes that Ashkenaz lies east of Loter. Thus, both terms were used in the same context and carried different meanings: ${ }^{19}$

This is the writing called "sats ha-mate," which was decided and introduced by our Master Samuel, the son of our Master Meir, and of Master Jacob, son of Master Meir and of Master Isaac ... [The text] was sent to the entire Diaspora in the kingdom of Zarfat and Loter and Ashkenaz ...

\footnotetext{
${ }^{16}$ Concerning the translation "Bretagne" see Norman Golb, The Jews in Medieval Normandy: A Social and Intellectual History (Cambridge and New York, 1998), 175.

${ }^{17}$ In describing "Lorraine" here, Rabbenu Tam is indicating the medieval territory of the former Frankish "Lotharingia," between the future Western Frankish Empire and the future Eastern Frankish Empire. On "Lorraine/Lotharingia" as a medieval cultural and political concept see Thomas Bauer, Lotharingien als historischer Raum: Raumbildung und Raumbewußtsein im Mittelalter, Rheinisches Archiv 136 (Cologne, 1997), 12-43.

${ }^{18}$ On the meaning of the Hebrew term "Loter" see Ginsburger, "Lothringen," Germania Judaica, 1:160-63; Max Weinreich, "The Historical-Geographic Determinants: Loter, the Cradle of Yiddish," in History of the Yiddish Language, ed. Max Weinreich, trans. Shlomo Noble (Chicago, 1980), 328-47; idem, "Di historish-geografishe determinaten Loter, dem wigele von yidish," in Geshikhte fun der yidisher shprakh, 4 vols., ed. Max Weinreich (New York, 1973), 1:334-53, 3:344-81; Henri Gross, Gallia Judaica: Dictionnaire géographique de la France d'après les sources rabbiniques (Paris, 1897), 293-305. For further references to Loter see "be-Loter," in the Chronicle of Jacob b. Yequtiel of Rouen cited in Norman Golb, Jews in Medieval Normandy: A Social and Intellectual History [in Hebrew] (Jerusalem, 1976), 173, and English edition (Cambridge and New York, 1998), 550; see also "be-Eres Loter," "bekol malkut Loter" in Chronicle of Shlomo b. Shimshon cited in Haverkamp, Hebräische Berichte, 471 and n. 10, 474.

${ }^{19}$ MS London, British Library, Add. 27129 (Margoliouth no. 1081); Finkelstein, Jewish SelfGovernment, 159.
} 
The fact that circular letters under the authority of Rabbenu Tam were sent both to Loter and to Ashkenaz can be reconstructed from other transmissions. These prove that the circulars, containing the takkanot of Rabbenu Tam, were confirmed by signature by both Eliezer b. Shimshon in Cologne and Eliezer b. Natan in Mainz. ${ }^{20}$ Thus, the first of these recipients is to be sought in the community of Cologne, which was situated in the area known as Loter. ${ }^{21}$ The community of Mainz, represented by Eliezer b. Natan, could be the destination referred to as "Ashkenaz,"22 an understanding that also reflects the political reality of the city of Mainz and its surroundings, since, like Worms and Speyer, it never was viewed as part of Lorraine. ${ }^{23}$

If Mainz is to be found in "Ashkenaz," what kind of geographical phenomenon or political entity does "Ashkenaz" refer to in the twelfth century? After the demise of the Roman Empire, in the early Middle Ages, the duchies of five Germanic tribes were established east of the Rhine and the future Lorraine, later to become part of the Frankish Empire. ${ }^{24}$ After the partitions of the Frankish Empire (843, 855, 870, and 880), these duchies (Saxony, Franconia, Bavaria, Swabia, and Thuringia) began to form a separate entity. ${ }^{25}$

${ }^{20}$ See Yáaḳov Farbshțain, ed., Responsa of Maharam of Rothenburg (Meir ben Barukh) [in Hebrew], 3 vols. (Jerusalem, 2014/2015), vol. 1, Defus Prag, 577, § 1019; Yonatan Shraga Domb, ed., Responsa of R. Moshe Mintz, 2 vols. (Jerusalem, 1991), 2:502-03, § 102; Rainer Josef Barzen, ed., Taqqanot Qehillot Šum: Die jüdischen Gemeinden von Mainz, Worms und Speyer im hohen und späten Mittelalter, Monumenta Germaniae Historica. Hebräische Texte aus dem mittelalterlichen Deutschland 2, 2 vols. (Wiesbaden, 2019), 2:472-73 (Synopsis $\S 103[3])$. On the residence of Eliezer b. Shimshon in Cologne see Germania Judaica, 1:74; Ephraim E. Urbach, The Tosafists: Their History, Writings and Methods [in Hebrew], 5th ed., 2 vols. (Jerusalem, 1986), 1:179.

${ }^{21}$ See map 1.

${ }^{22}$ See also Rashi on BT Ketubbot 77b, "But in Ashkenaz I saw ...," as well as in his running commentary on BT Hullin 93a. Rashi surely refers here to the communities of Mainz and Worms, where he was lived and taught. See "Ashkenaz," EJ, 2:570.

${ }^{23}$ This area, containing the ShUM communities-Mainz, Worms, and Speyer-is also called "Rhenus" (see note 31) in Hebrew transmission. See Yonatan Shraga Domb, ed., Responsa of R. Yaakov Weil [in Hebrew] (Jerusalem 2001), 1:141, § 113. The area was never a part of the territory of Lotharingia/Lorraine; see Lugge, "Gallia" und "Francia" in Mittelalter, 53 n. 6. Knowing this, Weinreich nevertheless understood these three communities as part of a "Jewish" Loter, which in his view does not necessarily have to be territorially identical to a "Christian" Lorraine. It seems he was not familiar with the above-mentioned sources. See Weinreich, Loter (English), 335, 341; Loter (Yiddish), 1:341 (no. 89.3), 1:347 (no. 92). Concerning the territory of Lotharingia/Regnum Lotharii, between the Kingdom of France and the Regnum Teutonicum, see Bauer, Lotharingien, 12-43, 837-39, and maps 1-3 at the end of the book.

${ }^{24}$ Alfred Haverkamp and Friedrich Prinz, Europäische Grundlagen deutscher Geschichte, vol. 1 of Gebhardt Handbuch für deutsche Geschichte (Stuttgart, 2004), 336-62, § 10.

25 "A unity in diversity," as Luidbrand describes the empire of Otto the Great (912-973), out of the following lands: "Lotharingia," "Francia," "Suevia," "Bagoaria," and "Saxonum ac 
This political unit, known later also as "Regnum Teutonicum" (the German Kingdom), ${ }^{26}$ was initially formed as a union of these five tribal duchies alone, without Lorraine to the west. These duchies and their names were not unknown to thirteenth century Hebrew writers either. In one of his responsa Meir of Rothenburg mentions the following regions: ${ }^{27}$ Sassonia (Saxony), ${ }^{28}$ Franka (Franconia), ${ }^{29}$ Elsass (Alsace), ${ }^{30}$ Rhenus, ${ }^{31}$ and Baijern (Bavaria) ${ }^{32}$ Similarly, at the end of his ethical will, Judah he-Hasid mentions the geo-

Turingionum terra," see Joseph Becker, ed., Die Werke Liudprands von Cremona (Liudprandi Opera), Antapodosis II, 24, Monumenta Germaniae Historica, Scriptores Rerum Germanicorum 41 (Hanover 1915), 49; Lugge, "Gallia" und "Francia" in Mittelalter, 153 n. 388; Otto II (955-983) confirms the estate of his mother "in Elesazia, ... Francia, Turingia, Saxonia, Slauonia," see Theodor von Sickel, ed., Ottonis II et Ottonis III diplomata, Monumenta Germaniae Historica (Hannover, 1893), 123, line 109; Lugge, "Gallia" und "Francia” in Mittelalter, 153 n. 389; Brühl, Geburt zweier Völker, 80.

26 "Regnum Teutonicum/Teutonicorum." On the development and meaning of this term in the eleventh and twelfth centuries see Brühl, Geburt zweier Völker, 72-75; Eckhard MüllerMertens, "Regnum Teutonicum/Teutonicorum," Lexikon des Mittelalters 7 (2002), 601-2; idem, "Romanum imperium und regnum Teutonicorum: Der hochmittelalterliche Reichsverband im Verhältnis zur Karolingerzeit," Jahrbuch für Geschichte des Feudalismus 14 (1990): 47-54; Wolfgang Eggert, "Ostfränkisch - fränkisch - sächsisch - römisch - deutsch: Zur Benennung des rechtsrheinisch-nordalpinen Reiches bis zum Investiturstreit," Frühmittelalterliche Studien 26 (1992): 239-73.

${ }^{27}$ Farbshtain, Responsa of Maharam of Rothenburg, vol. 2, Defus Cremona, 89, § 117 (hereafter MRC 117). Already Abraham Berliner pointed out that Joseph Kara, in his commentary on Ezek 23:23, also divides Alemannia/Ashkenaz into the above-mentioned duchies"Saxony, Franconia, Bavaria, Swabia." See Abraham Berliner, "Geographisches," Hebräische Bibliographie 12 (1872): 12; Haim Tykocinski, "Schwaben," Germania Judaica, 1:322. Unfortunately, I could not determine which edition of Joseph Kara's commentary was available to Abraham Berliner. In the new "Keter" edition of this commentary, we find the following:

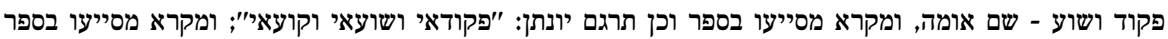

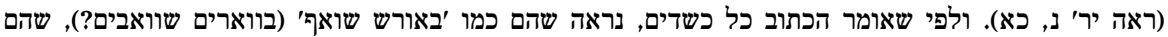

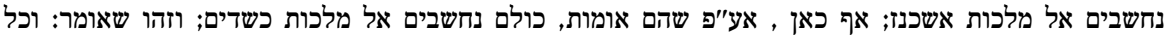
... כשדים - כל אומות המשועבדים למלכותות. See Joseph Kara's commentary on Ezek 23:22 (Cohen, Mikra'ot Gedolot 'Haketer') https://www.mgketer.org/tanach/14/23/23. In this text, the "Bavarians" and "Swabians," two "nationes" in the kingdom of "Ashkenaz," are only a possible reading of a difficult passage by the editor. More investigation on the version of this passage is needed.

${ }^{28}$ For further transmissions of the Hebrew term see Haim Tykocinski, "Sachsen," Germania Judaica, 1:313.

${ }^{29}$ On the Hebrew term see Haim Tykocinski, "Franken," Germania Judaica, 1:103.

${ }^{30}$ On the Hebrew term see Moses Ginsburger, "Elsaß," Germania Judaica, 1:96-97.

${ }^{31}$ On the Hebrew term see Adolf Kober, "Rhein," Germania Judaica, 1:306. See also "Rabbanei Rhenus," in Farbshtain, Responsa of Maharam of Rothenburg, vol. 2, Defus Lwow, 264, $\S 81$.

${ }^{32}$ On the Hebrew term see Haim Tykocinski, “Bayern,” Germania Judaica, 1:22. 
graphical term "Erez Shvaben (Swabia)."33 This political union of the five tribal duchies into the "regnum" (kingdom) may be attributable to a process that followed the Christianization of these regions in the seventh and eighth centuries $;{ }^{34}$ it became the foundation of a common culture of this "union" of territories. Only later, in the ninth century, was the Duchy of Lorraine incorporated into the united east-Frankish/early-German "regnum," a process that was consolidated in the tenth century. ${ }^{35}$ Nevertheless, because of its earlier Christianization and its Roman roots, Lorraine ("Lotharingia" = "Loter") continued to be perceived as a separate region in the following centuries, ${ }^{36}$ distinct from the five tribal duchies.

In written sources, a common factor and unifying element of the five duchies, alongside their political alliance under a common king, was the language they shared, called "theodisca lingua" in Latin (or, later, "diutsch" in German), ${ }^{37}$ which was also the source of a collective name, the "Teutonici" (later the "Diutschen"), ${ }^{38}$ used to signify the population that spoke this shared language. The twelfth century Hebrew chroniclers describing the events of the 1096 crusader riots followed this definition, using the name "Ashkenazim" ("Teutonici" = "Diutschen") for the region's gentile inhabitants, and distinguishing them from the "Zarfatim" 39 (populus Francorum, ${ }^{40}$

\footnotetext{
${ }^{33}$ Reuven Margaliot, ed., Sefer Hasidim (Jerusalem, 1957), 29, no. 56. On further transmissions of the Hebrew term see Haim Tykocinski, "Schwaben," Germania Judaica, 1:22.

${ }^{34}$ Lutz E. von Padberg, Christianisierung im Mittelalter (Darmstadt, 2006), 46-60.

${ }^{35}$ In the year 925 by King Henry I. See Bauer, Lotharingien, 5, 12.

${ }^{36}$ Bauer, Lotharingien, 12-43.

${ }^{37}$ Carl Erdmann, "Der Name Deutsch," in Karl der Große: oder Charlmagne? Acht Antworten deutscher Historiker, ed. Karl Hampo (Berlin, 1935), 95. On "theodisca," the Latin term for "theodisk/diutisce," the Germanic language shared by the five mentioned "nationes"-Saxons, Eastern Franks, Bavarians, Swabians, and Thuringians-and its history and meaning from the ninth to the eleventh century; see Brühl, Geburt zweier Völker, 62-69; Heinz Thomas, "Sur l'histoire du mot 'Deutsch' depuis le milieu du XIIe siècle jusqu'à la fin du XIIIe siècle," in Identité régionale e conscience nationale en France et en Allemagne du moyen âge à l'époque moderne, ed. Rainer Babel and Jean-Marie Moeglin, Beihefte der Francia 39 (Sigmaringen, 1997), 27-35; Rosemarie Lühr, "Deutsche Sprache," Lexikon des Mittelalters (Munich, 2002), 3:759.

${ }^{38}$ Brühl, Geburt zweier Völker, 71-72. On the long process of the formation of a "deutsches Volk" out of the five mentioned "nationes"-Saxons, Eastern Franks, Bavarians, Swabians, and Thuringians-see Brühl, Geburt zweier Völker, 84. But concerning the role of the German language see also Alfred Haverkamp, "Perspektiven Deutscher Geschichte während des Mittelalters," in idem, Gebhardt Handbuch, 1:91-96.

${ }^{39}$ See the chronicles of Eliezer b. Natan and Shlomo b. Shimshon in Haverkamp, Hebräische Berichte, 248-49. In the chronicle of Eliezer b. Judah Rokeah, the author uses the following expression: אומה זו האשכנזים, "this nation of the Germans"; see Neubauer and Stern, Hebräische Berichte, 76.

${ }^{40}$ Brühl, Geburt zweier Völker, 93.
} 
the "French," who spoke a distinctly different language). The collective term, which terminologically equates the German language area and the alliance of the five duchies into a common kingdom - whether called "Ashkenaz" or "diutsche lande" - can be found in a work by the poet Walter von der Vogelweide at the turn of the thirteenth century (1203). ${ }^{41}$ In his poem, "Ir sult sprechen willekomen" ("You shall welcome me") ${ }^{42}$ —in which he praises the German lands and their inhabitants, German women ("tiuschen frouwen") and German men ("tiusche man"), and their virtuous character ("tiuschiu zuht" = "German manners")—he describes the country's borders: ${ }^{43}$

Von der Elbe unz an den Rîn / und her wider unz an Ungerlant I mugen wol die besten sîn / die ich in der werlte hân erkant.

From the Elbe to the Rhine / and back to Hungary / there are the best people / I have ever seen in the world.

Noteworthy are the eastern borders of the "German lands" ("diutsche lande") on the Elbe River and the Hungarian border.

\section{Ashkenaz and its Eastern Borders}

The geographic localization of Ashkenaz, particularly its eastern border, was transmitted quite precisely in Hebrew writings from the thirteenth century that originated in the vicinity of Provence/Iberia. David Kimhi (d. 1235), commonly known as the Radak, was a contemporary of Judah he-Hasid who lived in southern France. Radak quite clearly describes what we have identified as "German lands," or "Regnum Teutonicum," in his biblical commentary on the book of Obadiah, where the prophet refers to the lands of Ashkenaz/Alemania: ${ }^{44}$

And these are the nations: The lands Alemania and Ashkelonia [Sklavonia/Slavonia] and Zarfat, which they call Fransia, ... It is said that the inhabitants of the land of Alemania were Canaan-

\footnotetext{
${ }^{41}$ Friedrich Maurer, Walter von der Vogelweide: Sämtliche Lieder (München, 1972), 81.

${ }^{42}$ Ibid., 80-83. On the poem and its author see also Ulrich Müller, "Das Mittelalterliche Reich in der Deutschen Literatur des Mittelalters," in Heilig, Römisch, Deutsch: Das Reich im Mittelalterlichen Europa, ed. Bernd Schneidmüller and Stefan Weinfurter (Dresden, 2006), 207-17, esp. 214-17.

${ }^{43}$ Maurer, Walter von der Vogelweide, 82 (verse 4).

${ }^{44}$ David Kimhi's commentary on Obad 1:20; Cohen, Mikra'ot Gedolot 'Haketer', 152-53. Translation by the author.
} 
ites, ${ }^{45}$ for when the Canaanites withdrew before the (approach) of Joshua, as is written in the Book of Joshua, they took off for the land of Alemania and Ashkelonia [Sklavonia/Slavonia], which are called the land of Ashkenaz. And they are called Canaanites [Slavs/Sclaves] until today.

At first, Kimhi's description seems unclear. Three countries are named: Zarfat, Alemania, and Ashkelonia. While "Zarfat" can probably be identified with the (northern) kingdom of France, or at least with the Île de France (the "royal domain," "Fransia"), ${ }^{46}$ the use of the term Ashkenaz alongside Alemania and Ashkelonia ${ }^{4 \dot{ }}$ is confusing. I therefore suggest an interpretation that is compatible with the historical political situation of the German lands at the turn of the eleventh to twelfth centuries. I believe Kimhi uses the term Erez Ashkenaz for the combined entity of Alemania and Ashkelonia (Sklavonia/Slavonia). The latter refers to the region bordering on Alemania (the German speaking areas, the "five duchies"), which in the eleventh and twelfth centuries was still primarily occupied by Slavs ("Canaanites" = Slavs/Sclaves). ${ }^{48}$ It may also imply the gradual pervasion and transformation

\footnotetext{
${ }^{45}$ The definition of the inhabitants of "Alemania" as Slavs ("Canaanites") is partially correct at least for the twelfth century in taking the eastern Slavic territories of the German Kingdom in consideration; see discussion above. See also Kraus, "Die Hebräischen Benennungen," 398-99. Further explanations can be found in an earlier meaning of the word "Kenaan"; see Rieger, "Deutschland," 457. Others view it as an older folk tradition; see Wallach, "Ashkenaz = Germany," 103 .

${ }^{46}$ Henri Gross, Gallia Judaica: Dictionnaire géographique de la France d'après les sources rabbiniques; Avec un supplément bibliographique, additions et corrections par Simon Schwarzfuchs (Amsterdam, 1969), 537.

${ }^{47}$ On the biblical origin of this term see Josh 13:3, meaning here the city of Ashkelon. It was Rieger who suggested the reading אשקלבוניה, "Ashklavonia" (Slavonia) instead of אשקלוניה, "Ashkelonia," understanding its meaning as the "Slavic lands." Rieger, "Deutschland," $457 \mathrm{n}$. 1. See also Kraus, "Die Hebräische Benennungen," 398. According to this interpretation see also the spelling אשכלבוניה, "Ashklavonia," Adler, Benjamin of Tudela, 72, and the following reference. On its meaning "Slavic lands" see Roman Jakobson and Morris Halle, "The Term Canaan in Medieval Hebrew," in For Max Weinreich on His Seventieth Birthday: Studies in Jewish Language, and Society, ed. Lucy S. Dawidowicz et al. (The Hague, 1964), 150-51, 154.

${ }^{48}$ This interpretation goes along with the understanding of Benjamin of Tudela. After his description of the Jewish communities in the "Land of Alemania" (ארץ אלימנייה), which includes mention of Regensburg, situated at the "edge of the kingdom" (קצה המלכות), Benjamin of Tudela continues as follows: "Thence extends the land of Bohemia (בהם), called Prague. This is the commencement of the land of Ashklavonia (ארץ אשכלבוניה, Sklavonia/Slavonia), and the Jews who dwell there call it Canaan (כנען), because the men of that land [the Slavs] sell their sons and their daughters to the other nations. These are the men of "Russia" (רוסיה, Russ/Kiev), which is a great empire stretching from the gate of Prague to the gates of Kiev (כיו), the large city which is at the extremity of that empire." See Adler, Benjamin of Tudela,
} 


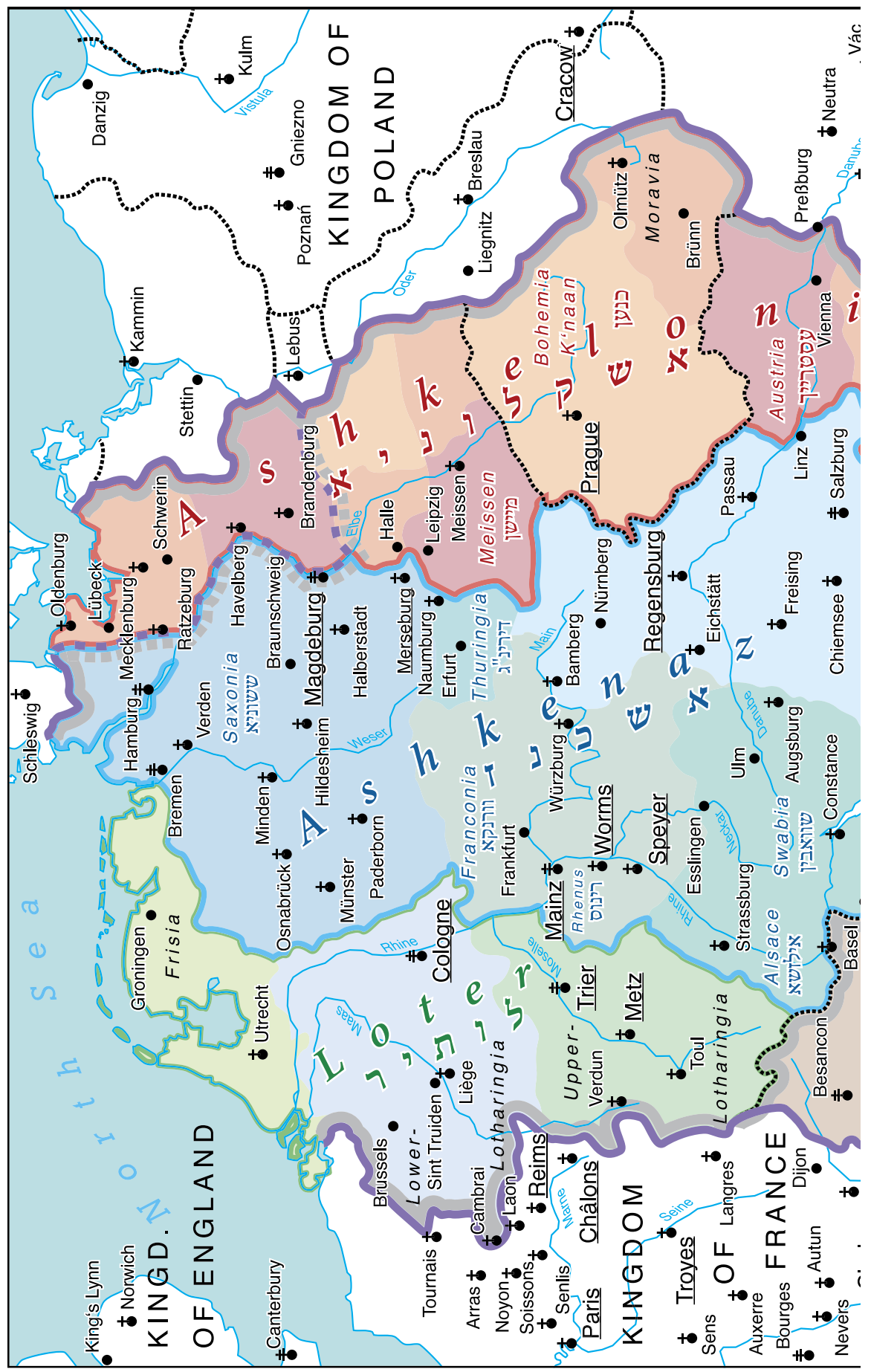




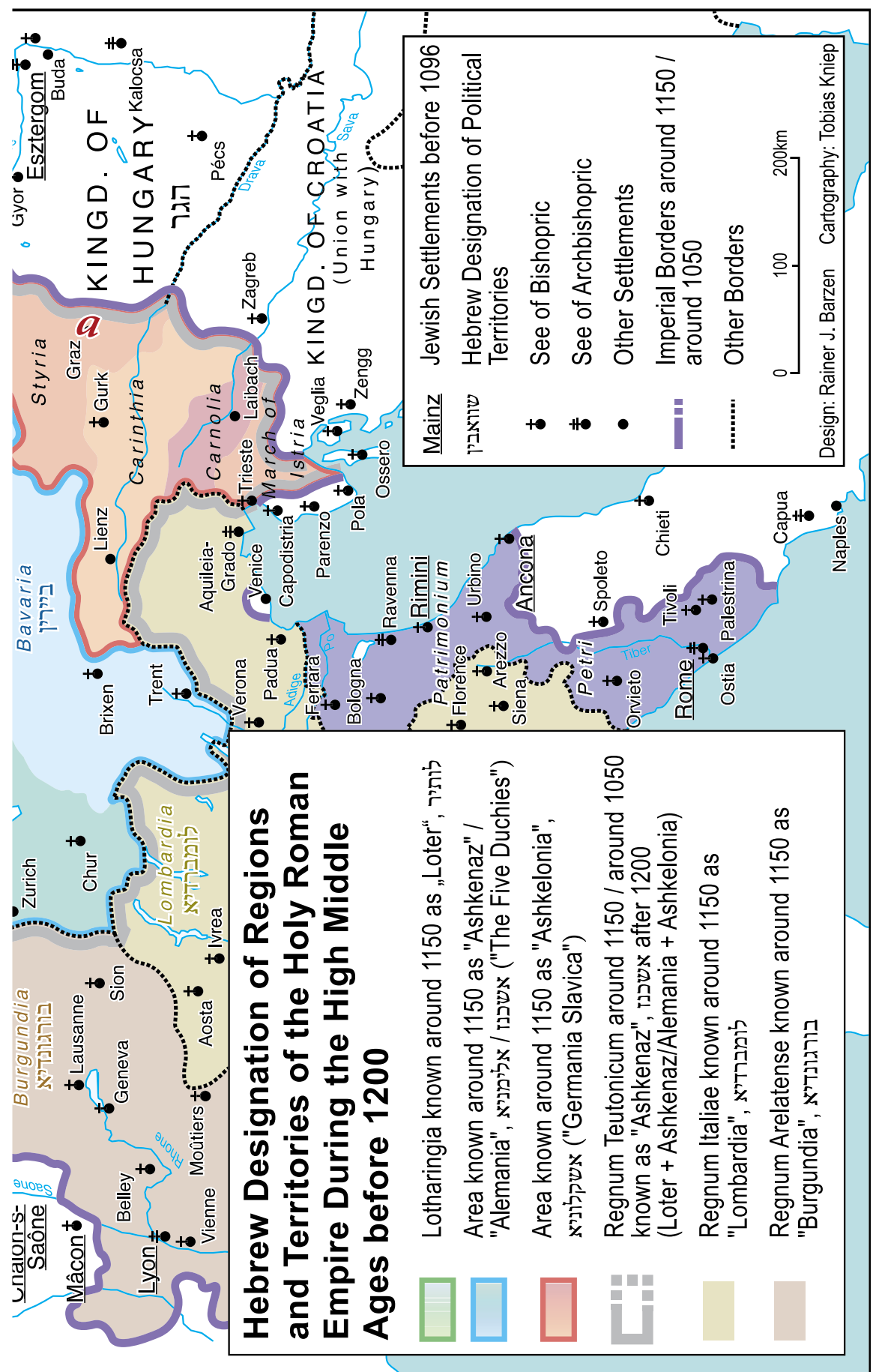




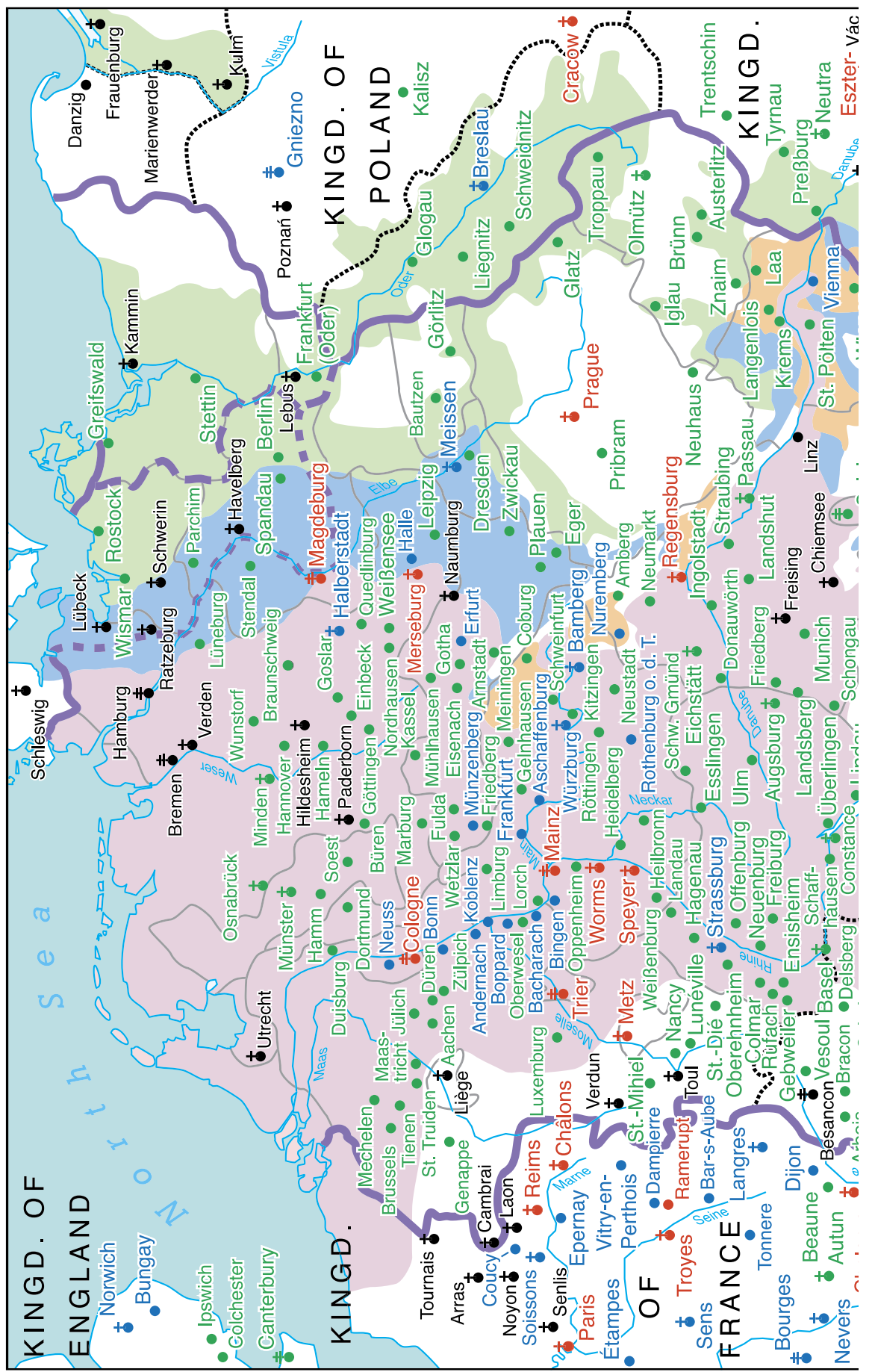




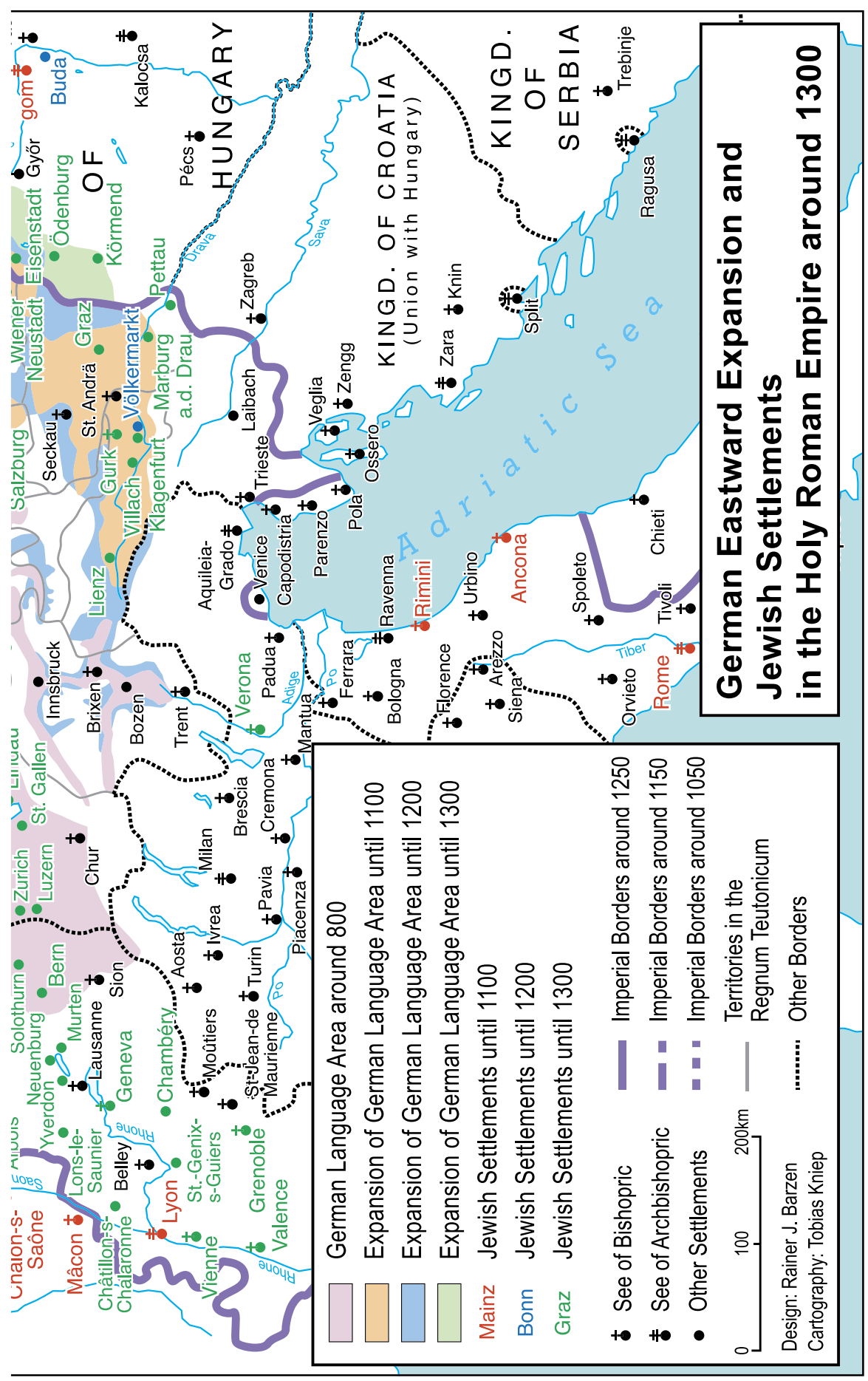


of Ashkelonia (Sklavonia/Slavonia) by the constant trickle of residents from "Alemania," the German speaking lands. On the other hand, the term "Ashkenaz" may stand for the "Regnum Teutonicum" itself, ${ }^{49}$ which, around 1200, already united the German speaking territories of the five duchies, the bilingual Lorraine, and the new, still Slavic-dominated territories in the East. ${ }^{50}$

Meir of Rothenburg was also familiar with the ethnic and linguistic distinctions between the aforementioned countries (Romance/French, Germanic/German, Slavic/Sorbian/Czech) and viewed these as the decisive characteristics for differentiating between these countries. It seems that "Zarfat" and the "island land (England)" and "Ashkenaz" and the "Land of Kenaan" are separate countries because their languages are distinct (from one another). ${ }^{51}$

Radak's description of the geopolitical situation quite precisely depicts the political and ethnic developments on the eastern edge of the German lands at the end of the twelfth century. For one, Radak was familiar with the use of the Hebrew name "Ashkenaz," alongside the Romance "Alemania," to indicate the German language area. But Radak also included the area bordering Ashkenaz on the east, which was still partly Slavic and was known to him as Ashkelonia (Sklavonia/Slavonia), and familiar to some of his contemporaries as Kenaan. ${ }^{52}$ This conforms to the political reality at the eastern edge of the five duchies in the twelfth century. Beginning in the tenth and eleventh centuries, new political entities had developed in the southeast through German settlements; in just a few generations these settlements had

72, 80-81. See also Dovid Katz, "Knaanic in the Medieval and Modern Scholarly Imagination," in Knaanic Language: Structure and Historical Background, ed. Ondřej Bláha, Robert Dittmann, and Lenka Uličná (Prague, 2013), 157. On the interpretation concerning the land of "Canaanites" (the Slavs) as the Land of slave traders see Gen 9:9-28 and Katz, "Knaanic," 185.

${ }^{49}$ See the terminology used by Benjamin of Tudela: "This is the commencement of the land of Alemania, a land of mountains and hills, and all the [Jewish] communities of Alemania are situated at the great River Rhine, from the city of Cologne, which is the head of the kingdom, until the city of Regensburg, a distance of fifteen days' journey at the other extremity of Alemania, otherwise called Ashkenaz." See Adler, Benjamin of Tudela, 71, 79. See also map 1 .

${ }^{50}$ Rieger, "Die Sprachen Deutschlands," 301.

${ }^{51}$ MRC 117.

${ }^{52}$ On the terminology "Kenaan" for the "Slavic lands," i.e., the land of the slaves from a western perspective, see Max Weinreich, "Yiddish, Knaanic, Slavic: The Basic Relationships," in For Roman Jakobson: Essays on the Occasion of His Sixtieth Birthday, ed. Morris Halle (The Hague, 1956), 623 n. 5; Jakobson and Halle, "The Term Canaan," 148-49. Rieger, "Die Sprachen Deutschlands," 301; Katz, "Knaanic," 181, 182 (map). On "Kenaan" as "Bohemia" see below n. 60 . 
transformed the eastern regions of the German empire, particularly in Austria, Carinthia, and Styria. ${ }^{53}$ Thus, the German language and settlement area was extended ${ }^{54}$ to the Hungarian border already in the eleventh century (as described by Walter von der Vogelweide), ${ }^{55}$ and by the twelfth century this situation was self-evident. This tendency toward political, ethnic, and linguistic expansion of the German lands continued to the northeast, crossing the Elbe and Saale rivers in the twelfth century and the Oder river in the thirteenth century (see map 2). ${ }^{56}$ New political entities were created within the new borders of the empire, based on existing Slavic tribal societies ${ }^{57}$ combined with the new German settlers; they became known as Meissen, Lusatia, Brandenburg, Mecklenburg, Pomerania, and Silesia. ${ }^{58}$ The formation of new German lands north and south of the Bohemian Basin and the

${ }^{53}$ See map 2 (colored in orange). Charles Higounet, Die deutsche Ostsiedlung im Mittelalter (München, 1990), 150-61.

${ }^{54}$ On this matter see map 2 and the different colors reflecting areas of new settlement and transformation.

${ }^{55}$ See notes 43 and 45 .

${ }^{56}$ This expansion was accompanied by an internal settlement movement in the western territories of the empire during the twelfth century. See Alfred Haverkamp, "Zwölftes Jahrhundert 1125-1198," in Gebhardt Handbuch für deutsche Geschichte, 5:27-34. On the "German eastward expansion" in general see Higounet, Die deutsche Ostsiedlung im Mittelalter; Walter Schlesinger, ed., Die deutsche Ostsiedlung des Mittelalters als Problem der europäischen Geschichte (Sigmaringen, 1975). On the shift of the German language border to the East between the years 1000 and 1500, as well as the German-Slavic language contact see Rolf Bergmann, "Deutsche Sprache und Römisches Reich im Mittelalter," in Heilig, Römisch, Deutsch, 165-66 with further references.

${ }^{57}$ On the so called "Germania Slavica," the western Slavic tribes between the Baltic Sea and the Alps see Haverkamp and Prinz, Europäische Grundlagen, 362-76, § 11; Wolfgang H. Fritze, ed., Germania Slavica I (Berlin, 1980); idem., Germania Slavica II (Berlin, 1981); Ludolf Kuchenbuch and Winfried Schich, eds., Frühzeit zwischen Ostsee und Donau: Ausgewählte Beiträge zum geschichtlichen Werden im östlichen Mitteleuropa vom 6. bis zum 13. Jahrhundert, Germania Slavica III (Berlin, 1982); Barbara Sasse, Die Sozialgeschichte Böhmens in der Frühzeit: Historisch-archäologische Untersuchungen zum 9.-12. Jahrhundert, Germania Slavica IV (Berlin, 1982); Wolfgang Ribbe, ed., Das Havelland im Mittelalter: Untersuchungen zur Strukturgeschichte einer ostelbischen Landschaft in slawischer und deutscher Zeit, Germania Slavica V (Berlin, 1987); Gertraud Eva Schrage, Slaven und Deutsche in der Niederlausitz: Untersuchungen zur Siedlungsgeschichte im Mittelalte, Germania Slavica VI (Berlin, 1990).

${ }^{58}$ Higounet, Die deutsche Ostsiedlung im Mittelalter, 108-50, 172-89; Marek Derwich, "Sachsen und Polen im 12. Jahrhundert," in Heinrich der Löwe und seine Zeit: Herrschaft und Repräsentation der Welfen 1125-1235, ed. Jochen Luckhardt und Franz Niehoff, 3 vols. (Munich, 1995), 2:136-43. 
Bohemian (Czech) kingdom ${ }^{59}$ (hereafter also called "Kenaan" 60 in Hebrew sources) was paralleled by an eastward extension of Ashkenazic Jewish settlements. Just a few generations later than Radak's description of the borders of "Ashkenaz," Jewish settlers, in a move corresponding to that of their German Christian neighbors, ${ }^{61}$ had created a new "Ashkenaz" ("East Ashkenaz") in the new eastern territories, ${ }^{62}$ alongside the "old Ashkenaz" (or "West Ashkenaz" $)^{63}$, and with it opportunities to establish new Jewish communities $^{64}$ and centers of Jewish scholarship. ${ }^{65}$ The new Jewish arrivals from the west to "East Ashkenaz" sometimes encountered preexisting Jewish com-

\footnotetext{
${ }^{59}$ On the German settlement in Bohemia and Moravia see Higounet, Die deutsche Ostsiedlung im Mittelalter, 161-72.

${ }^{60}$ For "Kenaan" as the Hebrew name for Bohemia see Jakobson and Halle, "The Term Canaan," 148-53; Rieger, "Die Sprachen Deutschlands," 301; Katz, "Knaanic," 157-58, 181. But for "Kenaan" as the general name for the Slavic lands see note 52.
}

${ }^{61}$ Alfred Haverkamp, "Germany," in vol. 6 of The Cambridge History of Judaism, The Middle Ages: The Christian World, ed. Robert Chazan (Cambridge and New York, 2018), 239-81, 252. See also map 2. This thesis is questioned by at least Max Weinreich ("Yiddish, Knaanic, Slavic," 624-25, n. 11). His rejection of a Jewish "Ostsiedlung" may be due to the fact that he does not take note of the strong gentile and Jewish settlement movement in the western part of the Empire during the twelfth century, which preceded the Jewish expansion in the East. On the other hand, Israel Ta-Shma sees in the existence of such a Jewish migration movement from west to east one of the main reasons for Judah he-Hasid and his family's move from Speyer to Regensburg in the second half of the twelfth century. Israel M. Ta-Shma, "On the History of the Jews in Twelfth- and Thirteenth-Century Poland," in Jews in Early Modern Poland, ed. Gershon David Hundert, Polin 10 (Oxford, 1997), 316.

${ }^{62}$ Michael Toch, "The Formation of a Diaspora: The Settlement of the Jews in the Medieval German Reich," Aschkenas 7, no. 1 (1997): 72-75; Alfred Haverkamp, "Jüdische Kultur beiderseits der Alpen in kulturlandschaftlichen Differenzierungen," in Wieczorek, Schneidmüller, and Weinfurter, Die Staufer und Italien, 1:328.

${ }^{63}$ Adapting the definition of Max Weinreich "Ashkenaz I" for the medieval German-speaking area, we may speak here as well of "Ashkenaz Ia (Old Ashkenaz/West Ashkenaz)" and "Ashkenaz Ib (New Ashkenaz/East Ashkenaz)." See above, n. 2.

${ }^{64}$ On the new Jewish settlements of the twelfth and thirteenth centuries in these new settlement areas (Mecklenburg, Pomerania, Brandenburg, Meissen, and Silesia) see further literature in "References Concerning Jewish Settlements until 1300" at the end of this article.

${ }^{65}$ As examples for scholars in new or renewed Jewish communities in the new territories of the east, see Hezekiah of Magdeburg, as well as Abraham Hildik and Jacob b. Nahman (both of Magdeburg). The latter two are known as authors of books of minhagim in the first half of the thirteenth century, perhaps in order to support the growing Jewish settlement. Concerning these sages and the Minhag Book of Abraham Hildik see also Rachel Zohn Mincer, "Liturgical Minhagim Books: The Increasing Reliance on Written Texts in Late Medieval Ashkenaz" (PhD diss., Jewish Theological Seminary of America, 2012), 226-69; Rachel Zohn Mincer, "The Increasing Reliance on Ritual Handbooks in Pre-Print Era Ashkenaz," Jewish History 31, no. 1-2 (2017): 110, 117; Ta-Shma, "History of the Jews," 296, 302-4. 
munities, not only in Prague, ${ }^{66}$ but also in Meissen, ${ }^{67}$ Spandau, ${ }^{68}$ and perhaps in Magdeburg, ${ }^{69}$ Vienna, ${ }^{70}$ and other places, which leads to the conclusion that Jewish settlement was also taking place from the east (Cracow, Kiev, and Constantinople) ${ }^{71}$ Likewise, there was lively interaction between the various Jewish cultural spheres, whereby - as with the German Christian settlements - the Ashkenazic tradition in its new local variants dominated, and in most cases displaced, the preexisting Jewish culture. ${ }^{72}$

At the borderline between the old German lands (West Ashkenaz) and the new German lands (East Ashkenaz), two cities stand out as the gateways to the new settlement regions: Magdeburg, a gateway for the new settlement

${ }^{66}$ On the Jewish community until the beginning of the thirteenth century see Haim Tykocinski, "Prag," Germania Judaica, 1:269-281. For the later thirteenth century see Zvi Avneri, "Prag," Germania Judaica, 2.2:659-62. On Czech as the mother tongue of the Jews in Prague and Bohemia during the thirteenth century see Jakobson and Halle, "The Term Canaan," 166. See also Katz, "Knaanic," 173.

${ }^{67}$ On the Jewish community until the beginning of the thirteenth century see Haim Tykocinski, "Meissen," Germania Judaica, 1:225-26. For the later thirteenth century see Siegbert Neufeld, "Meissen," Germania Judaica, 2.2:531-33. Isaac Or Zarua', who spoke a Slavic language as his mother tongue, spent years of his childhood in Meissen (around 1200). See Urbach, Tosafists, 1:436-437; Haim Tycoinski, "Lebenszeit und Heimat des Isaak Or Sarua," in Monatsschrift für die Geschichte und Wissenschaft des Judentums 55 (1911): 478-500, 488-89, and 493.

${ }^{68}$ In Spandau, the oldest tombstones with Hebrew inscriptions have been excavated. The Slavic names used for Jewish women buried there may underline the possibility of a non-Ashkenazic Jewish presence in that area before the immigration of Jews from western Germany. See Michael Brocke, "Die mittelalterlichen jüdischen Grabmale in Spandau (1244-1474)," in Ausgrabungen in Berlin 9 (1994), 8-116; Ernst Fraenkel, "Spandau," Germania Judaica, 2.2:772-74.

${ }^{69}$ On the Jewish community until the beginning of the thirteenth century see Haim Tykocinski, "Magdeburg," Germania Judaica, 1:163-70. For the later thirteenth century see Zvi Avneri and Daniel Goldschmidt, "Magdeburg," Germania Judaica, 2.2:505-10. See also Mincer, "Liturgical Minhagim Books," 29-31.

${ }^{70}$ On the Jewish community until the beginning of the thirteenth century see Haim Tykocinski, "Wien," Germania Judaica, 1:397-425. For the later thirteenth century see Joshua Amir and Leopold Moses, "Wien," Germania Judaica, 2.2:886-903.

${ }^{71}$ Like the early Jewish migration to Poland, see Ta-Shma, "History of the Jews," 291; Omeljan Pritsak, "The Pre-Ashkenazic Jews of Eastern Europe in Relation to the Khazars, the Rus' and the Lithuanians," in Ukrainian-Jewish Relations in Historical Perspective, ed. Peter J. Potichnyj and Howard Aster (Edmonton, 1988), 9, 10, 14; Wolf Moskovich, Shmuel Shvarzband and Anatoly Alekseev, eds., The Knaanites: Jews in the Medieval Slavic World, Jews and Slavs 24 (Jerusalem, 2014).

${ }^{72}$ See Ta-Shma, "History of the Jews," 314-17. On fifteenth-century Jewish Cracow/Kazimierz as an example for the described developments see Elchanan Reiner, "That All the Great Men of this Land are His Disciples': Rabbi Ya'akov Pollack of Cracow; First and Foremost among Cracow's Scholars" [in Hebrew], in Kroke-Kazimierz-Cracow: Studies in the History of Cracow Jewry, ed. Elchanan Reiner (Tel Aviv, 2001), 51-53. 
movement to the northeast, and Regensburg (where Judah he-Hasid lived), as the starting point for trade and transport, communication of ideas, goods, and people southeastwards (to Austria, Hungary, and Byzantium) and eastwards (to Bohemia/Prague, Poland/Cracow, and Russ/Kiev). ${ }^{73}$

\section{Regensburg in the Twelfth and Thirteenth Centuries}

When the pious Kalonymides of the Rhineland moved from Speyer to Regensburg in the second half of the twelfth century, ${ }^{74}$ or perhaps even decades earlier, ${ }^{75}$ it only appears that this prominent branch of the Kalonymous family moved its residence from the center to the periphery of the German kingdom. While as seen in the settlement map, ${ }^{76}$ Regensburg lies in the extreme east of the old German language area, in the transitional zone to the new settlements and the Slavic world, due to its Roman roots in the twelfth century it is comparable to the Rhenish cities. Ever since the development of the Bavarian tribal duchy and until the days of emperor Frederick I Barbarossa, and thus also Judah he-Hasid, Regensburg served as the duchy's spiritual and political center, the seat of the local bishopric, the seat of one of the most important monasteries of Bavaria (St. Emmeran ${ }^{77}$ ), and the residence of the Bavarian duke. ${ }^{78}$ Its function as a gateway to its neighbors to the east and to the kingdom's new territories was reflected in the city's economic rise, manifested in its building projects, especially the building of the Stone Bridge

\footnotetext{
${ }^{73}$ The mentioned routes and connections to the east correspond to the description of the known Jewish traveler from twelfth-century Regensburg, R. Petahiah; see Lazar Grünhut, ed. and trans., The Itinerary of R. Petchiah of Regenburg / Die Rundreise des R. Petachja aus Regensburg [in Hebrew with German translation] (Frankfurt and Jerusalem, 1904/05).

${ }^{74}$ Ta-Shma, "History of the Jews," 314; Eva Haverkamp, "Jews in Christian Europe: Ashkenaz in the Middle Ages," in The Wiley-Blackwell History of Jews and Judaism, ed. Alan T. Levenson (Malden, MA, 2012), 169-206.

${ }^{75}$ Ephraim Shoham-Steiner, "Exile, Immigration and Piety: The Jewish Pietists of Medieval Germany, from the Rhineland to the Danube," Jewish Studies Quarterly 24, no. 3 (2017): 235, 243-45, 259.

${ }^{76}$ See map 2.

${ }^{77}$ On the monastery of St. Emmeran and its influence on the Bishop of Regensburg and the Duke of Bavaria in and beyond the Salian Period see Lothar Kolmer, "Regensburg in der Salierzeit," in Die Salier und das Reich, vol. 3: Gesellschaftlicher und ideengeschichtlicher Wander im Reich der Salier, ed. Stefan Weinfurther (Sigmaringen, 1992), 202-8. See also the contribution of Adam S. Cohen in this volume.

${ }^{78}$ On Regensburg as the seat of the duke and capital of Bavaria see Peter Schmid, Regensburg: Stadt der Könige und Herzöge im Mittelalter, Regensburger historische Forschungen 6 (Kallmünz/Oberpfalz, 1977), 38-81, 435; Peter Schmid, "Ratispona metropolis Baioariae: Die bayerischen Herzöge und Regensburg," in Geschichte der Stadt Regensburg, ed. Peter Schmid, 2 vols. (Regensburg, 2000), 1:51-72; Kolmer, "Regensburg in der Salierzeit," 191-202.
} 
(1135/1146) as the city's economically vital crossing point. During the Salian (1024-1125) and Staufer (1138-1254) eras, Regensburg was one of the most important residences of the Roman-German kings and emperors in the Holy Roman Empire. ${ }^{79}$ During the reign of Emperor Frederick I, the emperor was as frequently present in Regensburg as in the Rhenish cathedral cities. ${ }^{80}$ The city's geopolitical significance as the gateway to the east and the route to Constantinople and the Orient along the Danube River was more than evident to the twelfth century emperors. Both the Second Crusade (1146) under Conrad III and the Third Crusade (1189) under Emperor Frederick I began in Regensburg $;{ }^{81}$ Judah he-Hasid most probably witnessed the latter event.

The Jewish community that the Rhenish Kalonymous family (Judah he-Hasid, his brother, and his father) joined was one of the oldest in twelfth century Ashkenaz. ${ }^{82}$ While the Regensburg community was not blessed with a large number of transregional scholars, it should be noted that some of these scholars-Ephraim b. Isaac, Moses b. Yoel, and Isaac b. Mordechai-were in contact with centers in France and had studied under Rabbenu Tam. ${ }^{83}$

The community's reputation seems to have suffered from its behavior during the persecutions of the First Crusade in 1096, where unlike their brothers in faith along the Rhine, the majority of the Jewish community preferred to temporarily convert rather than die as martyrs. Accepting figures of authority from the ShUM communities, with their strict practices of asceticism and their restrictive notions of piety, might have helped move their forefathers' disgrace into the background. ${ }^{84}$ What is certain is that the presence of the Rhenish Kalonymous family, the most prominent representatives of Rhenish

\footnotetext{
${ }^{79}$ Schmid, Regensburg, 37; Kolmer, "Regensburg in der Salierzeit," 92-213, 198.

${ }^{80}$ See the itinerary of Frederick I Barbarossa; Ferdinand Opll, "Kaiser Friedrich I. Karte der Aufenthaltsorte 1152-1189," in Die Zeit der Staufer: Geschichte, Kunst, Kultur, vol. 4: Karten und Stammtafeln, ed. Reiner Haussherr and Christian Väterlein (Stuttgart, 1977), map 3.

${ }^{81}$ On Regensburg as a starting point for the Third Crusade see Arnold Bühler, Der Kreuzzug Friedrich Barbarossas 1187-1190: Bericht eines Augenzeugen, Fremde Kulturen in alten Berichten 13 (Stuttgart, 2005), 78.

${ }^{82}$ Aron Freimann, "Regensburg," Germania Judaica, 1:285-304, 286; Siegfried Wittmer, Jüdisches Leben in Regensburg vom frühen Mittelalter bis 1519 (Regensburg, 2001).

${ }^{83}$ Abraham (Rami) Reiner, "From Rabbenu Tam to R. Isaac of Vienna: The Hegemony of the French Talmudic School in the Twelfth Century," in The Jews of Europe in the Middle Ages (Tenth to Fifteenth Centuries): Proceedings of the International Symposium held at Speyer 20-25 October 2002, ed. Christoph Cluse (Turnhout, 2004), 273-81, 277; idem, "Rabbenu Tam: His (French) Teachers and his Students from Ashkenaz" [in Hebrew] (master's thesis, The Hebrew University of Jerusalem, 1997), 68, 79. On the presence of Jewish sages in Regensburg in the eleventh and twelfth centuries, especially the Makhiri family, see also Avraham Grossman, The Early Sages of Ashkenaz: Their Lives, Leadership and Works (900-1096) [in Hebrew] (Jerusalem, 1988), 28, 29, 230, 365, 392.

${ }^{84}$ Shoham-Steiner, "Exile, Immigration and Piety," 245-46, n. 30.
} 
Hasidism, raised the stature of the Regensburg congregation interregionally. This was first evident in the person of Judah he-Hasid and how he functioned and was perceived already during his lifetime. Judah he-Hasid seems to have taken an important position within the community, as is indicated by a source referring to his donation for the renovation work on the synagogue. ${ }^{85}$ As a member of one of the most important scholarly families and as the key figure of a small, radical religious group, through the writing of responsa Judah he-Hasid became the spiritual leader of circles of Jewish scholars both from communities in the old western territories ${ }^{86}$ and from communities beyond the old boundary between Germania and Slavica. ${ }^{87}$ These included not only representatives of preexisting Jewish communities in Bohemia ${ }^{88}$ and Poland ${ }^{89}$ but also members of the communities characterized by increasingly hybrid Jewish traditions, in settlements in the new German territories such as Meissen or perhaps even Vienna. The orientation to the east was natural for the Jews of Regensburg as well, as the accounts of Petachia's travels from Regensburg to the east ${ }^{90}$ demonstrate. The fact that scholars from former or still Slavic territories of the following generation moved freely along both sides of the old line of demarcation between east and west is made clear by biographies of people like Isaac Or Zarua ${ }^{, 91}$ and others. ${ }^{92}$

\section{The Geographical Boundaries of Judah he-Ḥasid's World}

The extent to which these new geographical realities of east and west, of old communities and newly established communities, belonged to the everyday

\footnotetext{
${ }^{85}$ At least according to a transmission from the fifteenth century. See Yonathan Shraga Domb, ed., Responsa of R. Moshe Mintz [in Hebrew], 2 vols. (Jerusalem, 1991), 2:363, § 76.

${ }^{86}$ Responsa with Eliezer b. Judah ha-Roqeah of Worms (Urbach, Tosafists, 1:390-92); Simha of Speyer (Urbach, Tosafists 1:412); Barukh of Mainz (Urbach, Tosafists, 1:426).

${ }^{87}$ On his connection to the Jews in Magdeburg and Poland see Ta-Shma, "History of the Jews," 315 .

${ }^{88}$ With respect to Prague and its sages, Eliezer b. Isaac, who was also acquainted with the situation of the Jewish communities in Hungary, Poland, and "Russia (Russ/Kiev)," was in correspondence with Judah he-Hasid and was younger than him. For Isaac b. Jacob ha-Lavan, a student of Rabbenu Tam, see Urbach, Tosafists, 1:212-16.

${ }^{89}$ Ta-Shma, "History of the Jews," 293 (Jacob Svara of Cracow) and 301 (Moshe Poler/Polak).

${ }^{90}$ See Grünhut, Itinerary of R. Petchiah of Regenburg.

${ }^{91}$ The Or Zarua' was born and raised in Bohemia and lived in Meissen, Prague, Regensburg, Würzburg, France, Paris, and Vienna; see Urbach, Tosafists, 1:436-39; Germania Judaica, 1:400-410.

${ }^{92}$ Like his friend and colleague Abraham b. Azriel, the author of Arugat ha-Bosem; see Urbach, Tosafists, 1:402. On Abraham b. Azriel and his work see also the contribution of Elisabeth Hollender in this volume.
} 


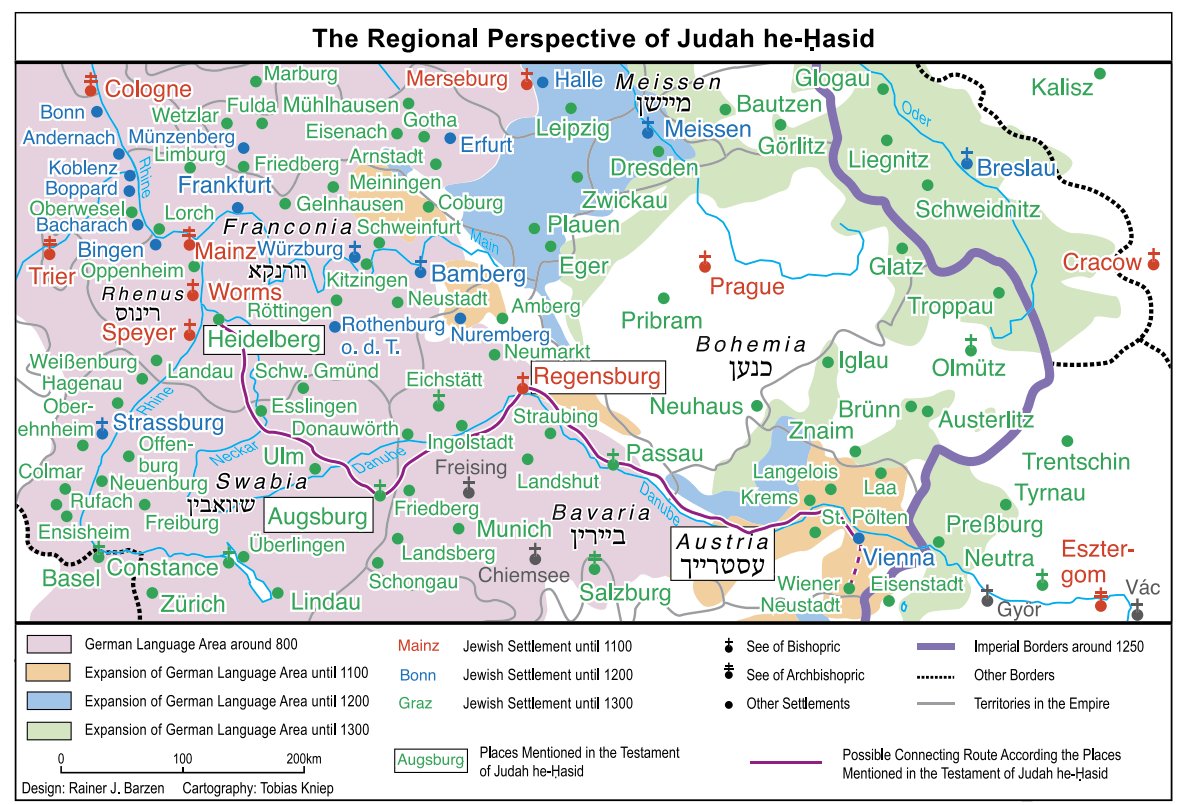

reality of Judah he-Hasid and were reflected by him is made clear by a fascinating, but obscure, note at the end of his so-called "testament": 93

No rabbi should settle in Heidelberg, for he will not long survive. No kohen should settle in Regensburg, neither should Eleazar [of Worms]. No one should settle in Augsburg. No married couple should settle ... in Austria, but if it has already happened, they should leave the duchy (malkut) every year for one month.

If we look at the geographical entities mentioned in this quote, and the order in which they are mentioned, we can trace a path from Heidelberg, not far from Speyer (Judah's previous residence) and under the purview of the ShUM communities, the old center of the west; via Augsburg, a new, young community, still in the west; to Regensburg, Judah he-Hasid's new place of residence and the center of the geographical space referred to in the quote; and finally to Austria (probably Vienna) in the new east, at the other geographical end of the list. It stands to reason, given the nature of Rabbi Judah's ethical will, that during the time the testament was drawn up, all of the places mentioned possessed Jewish residents who either sympathized with Judah he-Hasid's position or reacted to it. Rabbi Judah, therefore, is leaving

\footnotetext{
${ }^{93}$ See Margaliot, Sefer Hasidim, 28, no. 51. Translation by the author. On the ethical will and testament of Judah he-Hasid see Ivan G. Marcus, Sefer Hasidim and the Ashkenazic Book in Medieval Europe (Philadelphia, 2018), 34. Also see Maoz Kahana's paper in this volume.
} 
instructions for people close within his small religious circle, ${ }^{94}$ for whom he feels himself responsible and over whom he claims a high level of authority. ${ }^{95}$ The dispersion of these followers from the Middle Rhine to Austria corresponds to the geographical trajectory of his own life, but also to the pattern of new Jewish settlement movements, from the ShUM communities to the old peripheries, from the old centers to the new centers, from "old Ashkenaz" to the "new Ashkenaz," from west to east.

Acknowledgments I wish to thank the editors of this special volume of Jewish History-Elisheva Baumgarten, Elisabeth Hollender, and Ephraim Shoham-Steiner-for the opportunity to present my cartographic reflections alongside my article. Special thanks are owed to Elisheva Baumgarten for providing the financial support through the ERC grant "Beyond the Elite: Jewish Daily Life in Medieval Europe" for the language editing and to Katrin Kogman-Appel (Institut für Jüdische Studien / Institute for Jewish Studies, University of Münster) for her support of the cartographic representation. I owe special thanks to my cartographer, Mr. Tobias Kniep (Institut für vergleichende Städtegeschichte / Institute for Comparative Urban History, University of Münster), for his expert design of the maps and great patience, as well as to Mrs. Sara Tova Brody for her language expertise. My thanks to PD Dr. Eveline Brugger and PD Dr. Birgit Wiedl, both of the Institute for Jewish History of Austria at St. Pölten as well as Dr. Jörn R. Christophersen of the University of Frankfurt am Main and Dr. Maike Lämmerhirt of the University of Erfurt for their invaluable comments and suggestions. All errors and mistakes are my own.

The publication of this volume was supported by the "Beyond the Elite: Jewish Daily Life in Medieval Europe" research project (PI Elisheva Baumgarten), funded by the European Research Council under the European Union's Horizon 2020 research and innovation programme (grant 681507).

\section{Notes on the Form and Content of the Cartographic Representations}

\section{Map 1 (Hebrew Designation)}

Based on the sources listed in this article, Map 1 graphically illustrates how Jewish authors of the twelfth and thirteenth centuries assigned their own Hebrew terminologies to existing political-geographical spaces. The boundaries shown refer to political territories and spatial concepts in the contemporaneous Christian environment.

\footnotetext{
${ }^{94}$ On the idea of a "circle," not a "movement," that surrounded Judah he-Hasid see Marcus, Sefer Hasidim and the Ashkenazic Book, 72-74.

${ }^{95}$ Ta-Shma, "History of the Jews," 316.
} 
Map 2 (Jewish Settlements) and Map 3 (Regional Perspective)

My intention was to map all known Jewish settlements of the eleventh, twelfth, and thirteenth centuries documented in the source literature discussed in the article. However, due to the scale and size of the map this task is virtually impossible. This is especially true of regions that already had a relatively high density of Jewish settlements during this period. These include Champagne, the Rhineland, as well as Alsace, Swabia, Franconia, Hesse, western Switzerland, the Franche-Comté, Burgundy, and Lorraine. For these regions see the detailed atlas in Haverkamp, Geschichte der Juden im Mittelalter von der Nordsee bis zu den Südalpen, that presents a nuanced, comprehensive cartographic representation.

In general, the data relating to the twelfth century in the accompanying maps is complete, while the representation of the Jewish settlement in the thirteenth century west of the Holy Roman Empire, east of the Kingdom of France, is partial due to the map's scale.

For the Jewish settlements in present-day eastern Germany, to the east of the Elbe and Saale, as well as in the territory of present-day Austria, Slovenia, the Czech Republic, Slovakia, Hungary, and Poland, I strived to present a complete picture of the known Jewish settlements for the entire period.

\section{References Concerning the Maps}

Geographical frontiers of the German language and political frontiers:

Rolf Bergmann, "Deutsche Sprache und römisches Reich im Mittelalter," in Heilig, Römisch, Deutsch: Das Reich im Mittelalterlichen Europa, ed. Bernd Schneidmüller and Stefan Weinfurter (Dresden, 2006), 162-84; maps 1-3, 5; 180-84.

Gerd Althoff, "Die Ottonen," in Heiliges Römisches Reich Deutscher Nation 962 bis 1806: Von Otto dem Grossen bis zum Ausgang des Mittelalters, ed. Matthias Puhle and Claus-Peter Hasse, 2 vols. (Dresden, 2006), 1:74-85, 79 (map).

Stefan Weinfurter, "Die Salier," in Puhle and Hasse, Heiliges Römisches Reich, 2:137-45, 145 (map).

Knut Görich, "Die Staufer," in Puhle and Hasse, Heiliges Römisches Reich, 2:186-97, 197 (map).

Heinz Musall and Arnold Scheuerbrandt, "Natur- und kulturräumliche Gegebenheiten der drei Regionen zur Stauferzeit," in Die Staufer und Italien: 
Drei Innovationsregionen im mittelalterlichen Europa; Essays, ed. Alfred Wieczorek, Bernd Schneidmüller, and Stefan Weinfurter (Damrstadt, 2010), 163-76, 164-65 (on roads between Speyer and Regenburg).

Alfred Haverkamp, "Jüdische Kultur beiderseits der Alpen in kulturlandschaftlichen Differenzierungen," in Wieczorek, Schneidmüller, and Weinfurter, Die Staufer und Italien, 325-31, 328-29 (2 maps).

Erwin Gatz, ed., Atlas zur Kirche in Geschichte und Gegenwart: Heiliges Römisches Reich; Deutschsprachige Lände (Regensburg, 2009).

Werner König, ed., Dtv-Atlas der deutschen Sprache (Munich, 1983), 230 (map).

R. F. Treharne and Harold Fullard, Muir's Historical Atlas: Medieval and Modern (London, 1969), 10, 20 (maps).

Tomasz Góra, ed., Nowy Atlas historii Polski: Od pradziejów do wspótczesności (Warsaw, 2016), 11-13 (maps).

Walter Leisering, ed., Putzger historischer Weltatlas: Ausgabe mit Registern (Berlin, 1992), 42-43, 46-47, 50-51 (maps).

Hans-Erich Stier et. al., eds., Völker Staaten und Kulturen: Ein Kartenwerk zur Geschichte (Georg Westermann) (Braunschweig, 1979), 34, 38(1), 40(1), 42(1) (maps).

References Concerning Jewish Settlements until 1300:

(Eastern France, the West of the Regnum Teutonicum, the Regnum Italiae, and the Regnum Arelatense)

Henri Gross, Gallia Judaica: Dictionnaire géographique de la France d'après les sources rabbiniques; Avec un supplément bibliographique, additions et corrections par Simon Schwarzfuchs (Amsterdam, 1969). Germania Judaica: vol. 1, Ismar Elbogen, Aron Freimann, Haim Tykocinski, eds., Von den ältesten Zeiten bis 1238 (Breslau, 1934); vol. 2, Zvi Avneri, ed., Von 1238 bis zur Mitte des 14. Jahrhunderts, pt. 1, Aachen-Luzern, pt. 2, Maastricht - Zwolle (Tübingen, 1968); vol. 3, 1350--1519, pt. 1, Arye Maimon, ed., Ortschaftsartikel Aach - Lychen (Tübingen, 1987); pt. 2, Arye Maimon, Mordechai Breuer, and Yacov Guggenheim, eds., Ortschaftsartikel Mährisch-Budwitz - Zwolle (Tübingen, 1995); pt. 3, Arye Maimon, Mordechai Breuer, and Yacov Guggenheim, eds., Gebietsartikel, Einleitungsartikel und Indices (Tübingen, 2003); Alfred Haverkamp, ed., Geschichte der Juden im Mittelalter von der Nordsee bis zu den Südalpen, 3 vols., Forschungen zur Geschichte der Juden A.14/1-3 (Hannover, 2002). 
Alfred Haverkamp, "The Beginning of Jewish Life North of the Alps with Comparative Glances at Italy (ca. 900-1100)," in "Diversi Angoli di visuale" fra storia medievale e storia degli ebrei: In ricordo di Michele Luzzati atit del convegno, Pisa 1-3 febbraio 2016, ed. Anna Maria Pult Quaglia and Alessandra Maria Veronese, Biblioteca del Bollettino Storico Pisano, Collana storica 62 (Pisa, 2016), 85-102, 86.

On the Jewish settlements in the eleventh, twelfth, and thirteenth centuries in the new settlement areas (Mecklenburg; Pomerania; Brandenburg; Meissen; Lusatia, Silesia; Bohemia, Moravia; Austria, Salzburg, Carinthia, Styria, Tyrol; Hungary; Poland), see:

Mecklenburg: Christa Cordshagen, "Zur Geschichte der in Mecklenburg ansässigen Juden von den Anfängen bis 1492," in Wegweiser durch das jüdische Mecklenburg-Vorpommern, ed. Irene Diekmann, Beiträge zur Geschichte und Kultur der Juden in Brandenburg, Mecklenburg-Vorpommern, SachsenAnhalt, Sachsen und Thüringen 2 (Potsdam, 1998), 14-22; Gerhard Fouquet and Sven Rabeler, "Juden in den Ostseestädten Wismar und Rostock im Mittelalter - ein Vergleich," Jahrbuch für Regionalgeschichte 30 (2012): 17-36.

Pomerania: Uwe Rodig, "Die Überlieferung von Quellen im Landesarchiv Greifswald zur Geschichte der jüdischen Bevölkerung in Pommern," in Żydzi szczecińscy. tradycja i współczesność: Materiały z sesji naukoweij 27 czerwca 2003, ed. Kazimierz Kozłowski and Janusza Mieczkowskiego (Szczecin, 2004), 103-7.

Meissen: Maike Lämmerhirt, Juden in den wettinischen Herrschaftsgebieten: Recht, Verwaltung und Wirtschaft im Spätmittelalter (Cologne, 2007), $7-47$.

Brandenburg: Jörn Roland Christophersen, "Jüdische Friedhöfe und Friedhofsbezirke in der spätmittelalterlichen Mark Brandenburg," in Pro multis beneficiis: Festschrift für Friedhelm Burgar; Forschungen zur Geschichte der Juden und des Trierer Raums, ed. Sigrid Hirbodian, Christian Jörg, Sabine Klapp, and Jörg R. Müller, Trierer historische Forschungen 68 (Trier, 2012), 129-46; idem, "Studien zur Geschichte der Juden in der Mark Brandenburg während des späteren Mittelalters" (PhD diss., University of Trier, 2008).

Silesia: Israel M. Ta-Shma, "On the History of the Jews in Twelfth- and Thirteenth-Century Poland," in Jews in Early Modern Poland, ed. Gershon David Hundert, Polin 10 (1997), 287-317; Marcin Wodzinski, Hebrajskie inskrypcje na Ślqsku XIII-XVIII wieku (Wrocław, 1996); Marcin Wodzinski and Janusz Spyra, eds., Jews in Silesia: Papers from a Conference Held in May 2000 at the University of Wroctaw (Krakow and Wrocław, 2001); Norbert Conrads, "Die verlorene 'Germania Judaica': Ein Handbuch- und 
Autorenschicksal im Dritten Reich," Berichte und Forschungen: Jahrbuch des Bundesinstituts für Kultur und Geschichte der Deutschen im Östlichen Europa 15 (2007): 215-54; Zofia Kowalska, "Die Anfänge der jüdischen Ansiedlung in Oberschlesien im 12. und 13. Jahrhundert," Oberschlesisches Jahrbuch 14/15 (2000): 13-29.

Bohemia, Moravia: Eva Doležalová, ed., Juden in der mittelalterlichen Stadt: Der städtische Raum im Mittelalter - Ort des Zusammenlebens und des Konflikts / Jews in the Medieval Town: Urban Space in the Middle Ages A Place of Coexistence and Conflicts (Prague, 2015). Daniel Soukup, "Apostatrix gens: The First Crusade and Criticism of the Reversions of Jews in Cosmas's Chronica Boemorum (Chronicle of the Bohemians)," in Doležalová, Juden in der mittelalterlichen Stadt, 9-26; Tamás Visi, "Rabbinic Sources about Jews in Medieval Moravia," in Doležalová, Juden in der mittelalterlichen Stadt, 103-23. Petr Schneider, "Ein Fund von Brakteaten mit hebräischer Umschrift aus der Nähe von Anenský vrch bei Mikulov (Südmährische Region, Bez. Břeclav)," in Doležalová, Juden in der mittelalterlichen Stadt, 139-48.

Austria, Salzburg, Carinthia, Styria, Tyrol: Eveline Brugger and Birgit Wiedl, Regesten zur Geschichte der Juden im Mittelalter, vol. 1: Von den Anfüngen bis 1338 (Innsbruck, 2005).

Hungary: Katalin Szende, “Traders, 'Court Jews', Town Jews: The Changing Roles of Hungary's Jewish Population in the Light of Royal Policy between the Eleventh and Fourteenth Centuries," in Intricate Interfaith Networks in the Middle Ages: Quotidian Jewish-Christian Contacts, ed. Ephraim Shoham-Steiner, Studies in the History of Daily Life (800-1600) 5 (Turnhout, 2016), 119-51, 133 (map).

Poland: Shmuel Arthur Cygielman, The Jews of Poland and Lithuania until 1648 (5408): Prolegomena and Annotated Sources [in Hebrew] (Jerusalem, 1991), 25-33, map (at the end of the book); Jürgen Heyde, "Jüdische Siedlung und Gemeindebildung im mittelalterlichen Polen," in Jüdische Gemeinden und ihr christlicher Kontext in kulturräumlich vergleichender Betrachtung von der Spätantike bis zum 18. Jahrhundert, ed. Christoph Cluse, Alfred Haverkamp, and Israel Jacob Yuval, Forschungen zur Geschichte der Juden A 13 (Hannover, 2003), 249-66, 252 and 261-66.

Funding Note Open Access funding enabled and organized by Projekt DEAL.

Publisher's Note Springer Nature remains neutral with regard to jurisdictional claims in published maps and institutional affiliations. 
Open Access This article is licensed under a Creative Commons Attribution 4.0 International License, which permits use, sharing, adaptation, distribution and reproduction in any medium or format, as long as you give appropriate credit to the original author(s) and the source, provide a link to the Creative Commons licence, and indicate if changes were made. The images or other third party material in this article are included in the article's Creative Commons licence, unless indicated otherwise in a credit line to the material. If material is not included in the article's Creative Commons licence and your intended use is not permitted by statutory regulation or exceeds the permitted use, you will need to obtain permission directly from the copyright holder. To view a copy of this licence, visit http://creativecommons.org/ licenses/by/4.0/. 